\title{
Spatiotemporal Variation Characteristics of Water Pollution and the Cause of Pollution Formation in a Heavily Polluted River in the Upper Hai River
}

\author{
Chunfang Meng $\mathbb{D}^{1,2}$ Xiaoyu Song $\mathbb{D}^{1},{ }^{1}$ Kening Tian, ${ }^{3}$ Bingxiao Ye, ${ }^{2}$ and Tianxiu $\mathrm{Si}^{2}$ \\ ${ }^{1}$ State Key Laboratory of Eco-Hydraulics in Northwest Arid Region of China, Xi'an University of Technology, Xi'an 710048, \\ Shanxi Province, China \\ ${ }^{2}$ Xinxiang Hydrology and Water Resources Survey Bureau, Xinxiang 453000, Henan Province, China \\ ${ }^{3}$ Henan Vocational College of Water Conservancy and Environment, Zhengzhou 450000, Henan Province, China
}

Correspondence should be addressed to Xiaoyu Song; songxy@xaut.edu.cn

Received 16 October 2020; Revised 29 November 2020; Accepted 16 December 2020; Published 30 December 2020

Academic Editor: Sedat Yurdakal

Copyright (c) 2020 Chunfang Meng et al. This is an open access article distributed under the Creative Commons Attribution License, which permits unrestricted use, distribution, and reproduction in any medium, provided the original work is properly cited.

\begin{abstract}
Blackening and odorization of heavily polluted rivers has become a serious concern and threat to ecological and human health. This paper aims to gain a deeper understanding of changes in water pollution and the cause of pollution formation in a heavily polluted river in the upper Hai River. In this study, comprehensive water quality index (CWQI) and multivariate statistical techniques (MSTs) were applied to assess the spatiotemporal variation characteristics of water pollution and to identify potential pollution sources. The seasonal Mann-Kendall (SMK) test and the SMK test of flow-adjusted concentrations were effectively used to explore the temporal variation trends of major pollutants and the causes of their formation. Data of 15 water quality parameters were analyzed during 1980-2018 at 19 monitoring sites in the mainstream and major tributaries of the Xinxiang Section of the Wei River (XSWR). The results showed that the rivers were seriously polluted from 1991 to 2009, but the water quality improved after 2010. Nineteen sampling sites were divided into a low pollution region and a high pollution region. In the flood season, the pollution sources were mainly domestic sewage, industrial wastewater, agricultural runoff, biochemical pollution, and natural sources. In the nonflood season, the pollution sources were mainly domestic sewage and industrial wastewater. In recent years, the water quality of seriously polluted river has generally improved, mainly due to reductions in pollutant discharge from point sources and nonpoint sources.
\end{abstract}

\section{Introduction}

A heavily polluted river called a black-odorous river often appears black or dark green and is accompanied by a strong, unpleasant odor, which seriously affects people's daily lives and threatens the aquatic ecosystem [1]. Eliminating blackodorous rivers is listed as an urgent task promulgated by the State Council of China [2]. Studies have shown that the spatiotemporal variations in water pollution are jointly determined by both natural factors and human activities, such as climate, geography, seasonal variation, land-use patterns, population density, and damming [3-5]. Human activities such as high-intensity development and utilization, dam and gate adjustment, and sewage discharges contribute significantly to the degree of blackening and odorization of water in heavily polluted rivers $[6,7]$. For effective water management, it is very important to collect reliable information about the water quality of heavily polluted rivers to assess spatiotemporal water quality changes, identify pollution sources, determine the status of water quality, and control water pollution in rivers [8].

The Hai River Basin is located in the semiarid region of the Northern Hemisphere. It is the political and cultural center of China, with numerous cities and a developed economy. Since the 1980s, there has been a widespread trend of drought in the upper plain $[9,10]$. Many seasonal water- 
deficient rivers are replenished by unconventional water resources such as sewage and wastewater and interbasin water transfer projects [11]. Point sources such as domestic sewage and industrial effluent as well as nonpoint sources related to agriculture have produced serious pollution loads [12]. River water pollution poses a serious threat to ecological functioning and the health of the local residents, and the issue of water security is very prominent. In recent years, with the addition of effective pollution control measures, the water quality of heavily polluted rivers is currently recovering, and the spatiotemporal variation characteristics of water pollution and the causes of pollution formation have changed. Understanding spatiotemporal variation characteristics of water pollution is very important for solving the pollution problem. However, at present, there are few studies on changes in the water pollution in heavily polluted rivers in the upper reaches of the Hai River. It is urgent and useful to evaluate the spatiotemporal variation characteristics of water pollution in heavily polluted rivers and further analyze the cause of changes in river pollution.

For a small river basin, human activities obviously impact the river water quality due to a river's sensitivity and vulnerability to external response in a short time [13]. In this study, the Wei River, as an important tributary of the upper Hai River, is selected as the study area for its representativeness in heavy pollution due to human activities in the Hai River Basin. Excessive anthropogenic input results in the blackening and odorization of this river, which seriously affects people's lives.

Water quality index (WQI) is widely used in the assessment of water quality of rivers and plays an important role in water resource management $[8,14]$. To determine the degree of blackening and odorization of surface water, $\mathrm{Xu}$ [15] described the comprehensive water quality index (CWQI) of surface water used to convert multiple water quality variables into a single number that reflects the status of water quality. CWQI has been successfully applied to assess river water quality in Shanghai, Nanjing, and other places [1].

In recent years, multivariate statistical methods (MSTs) such as cluster analysis (CA), discriminant analysis (DA), principal component analysis/factor analysis (PCA/FA), and multivariate linear regression (MLR) have been effectively applied to the assessment of surface water quality, evaluation of spatiotemporal variations in water quality, and identification of latent pollution sources by calculating only the observed data of water quality [16-19].

The increase in pollutant loadings is an important cause of the degradation of water quality. Quantifying the causeeffect relationship between pollutant sources and water quality variations allows regulators to implement targeted measures to control water pollution. In previous studies, various methods of analysis have been employed to identify river pollution sources, and methods have been classified into two categories: (i) diffusion models, such as QUAL, MIKE, WASP, and EFDC [20, 21], and (ii) receptor models such as the chemical mass balance model (CMB), the positive matrix factorization model (PMF), the UNMIX model, and absolute principal component score-multiple linear regression (APCS-MLR) [22-24]. Diffusion models can describe the fate and transport of water quality constituents in receiving water bodies. Therefore, pollutants can be spatially traceable [25]; however, taking the river basin as a unit and requiring a large amount of river basin data (such as meteorology, terrain, hydrology, soil type, and land use), the difficulty in data acquisition and the complexity of modeling is significant. Thus, it is time-consuming and difficult to apply, especially to rivers replenished by interbasin water transfer projects. Receptor models use the physical and chemical characteristics of pollution sources and sampling sites to analyze contributions of the pollution sources to each variable at sampling sites [26]. These methods are simple to operate and widely applied in pollution studies [27]. APCS-MLR, a popular receptor model, has recently been employed in the apportionment of pollution sources [26].

A literature review of these methods is presented below. CA is often used to effectively analyze spatiotemporal variations in water quality. Zhou et al. [27] applied CA to split the year into two periods, June-September and the remaining months, and divided the entire area into two parts representing different pollution levels in eastern Hong Kong. Furthermore, they considered appropriate data pretreatment, including estimation of missing data, examination of normal distributions, and data transformation, which can greatly influence the results of multivariate analysis. DA can confirm clusters determined by CA based on the accuracy of discriminant functions. Chen et al. [28] used DA to construct discriminant functions in three modes (standard mode, forward stepwise mode, and backward stepwise mode), which yielded a classification matrix correctly assigning $91.25 \%, 90.83 \%$, and $90.83 \%$ of the cases, respectively. In addition, Singh et al. [18] showed that DA offers important data reduction by using only six variables discriminating spatial pattern and two variables for temporal variation in the Gomti River in India.

PCA/FA is a dimension-reduction technique that has been used to identify latent factors or pollution sources [29]. Tanriverdi et al. [30] applied PCA to analyze and assess the surface water quality of the Ceyhan River. Three principle components (PCs) were extracted by PCA, which explained $79.14 \%$ of the total variation. Stations near cities were strongly affected by household wastewater, while other stations were influenced by agricultural facilities. In order to reduce the impact of less significant variables, PCs were rotated by a maximum variance method to create new variance factors (VFs) [26]. Bu et al. [13] also calculated total factor scores using PCA/FA and identified the water quality at each sampling site in a polluted river near Liaodong Bay in Northeast China. The higher the total factor score, the worse the river water quality.

APCS-MLR can provide quantitative contributions of each source type to each variable [27]. Su et al. [31] found that most variables were related to agricultural runoff $\left(\mathrm{NH}_{3}-\mathrm{N}, 85.3 \%\right.$; $\mathrm{COD}_{\mathrm{Mn}}, 74.2 \%$; DO, 69.9\%; and BOD, 70.5\%) and soil weathering (F, 78.9\%) for Zone D using the APCS-MLR in the Qiantang River in China. Furthermore, they also discovered that the concept of zoning should be 
taken seriously in water pollution control. Zhou et al. [27] studied source apportionment of coastal water pollution using the APCS-MLR method in eastern Hong Kong.

It is clear from the above literature review that many research studies have focused mainly on water quality variations in river basins or lakes but that attention has rarely been paid to the water pollution of heavily polluted rivers. Moreover, previous studies identified potential pollution sources and calculated the contribution of the potential pollution sources to each water quality parameter but did not further analyze the cause of pollution formation; that is, it is unknown whether pollution is caused by changes in flow or changes in pollution sources and whether pollution sources are mainly from point sources or nonpoint sources; answering these unknowns is key to solving the problem of water pollution. The seasonal Mann-Kendall (SMK) test and the SMK test of flow-adjusted concentrations can be used to analyze the change trend of water quality and the influence of flow and pollution sources on pollutant concentrations $[32,33]$ while simultaneously avoiding the influence of seasonality, lack of watershed data, and interbasin water transfer. CWQI, MSTs, and SMK test have some limitations when used alone for water quality assessment. Therefore, applying these mathematical instruments together can be more effective to assess water quality of heavily polluted rivers. However, few studies have used these mathematical instruments together for water quality assessment of heavily polluted rivers. It is therefore essential to perform an assessment of water quality and analyze the cause of pollution formation in heavily polluted rivers, especially in densely populated areas lacking data. A timely study would be not only essential but also instrumental in taking appropriate remedial action to improve the quality of the environment for sustainable development of the region.

Considering the above points, this paper took the Wei River as an example and used CWQI, MSTs, and the SMK test and the SMK test of flow-adjusted concentrations to analyze spatiotemporal variation characteristics of water pollution, the potential pollution sources, and the cause of pollution formation in the Xinxiang Section of the Wei River (XSWR) from 2013 to 2018. First, the water quality data were compared with the environmental quality standards for surface water of China to determine the major pollution parameters. Second, we also analyzed black-odorous levels by CWQI and the long-term temporal patterns of major pollutants from 1980 to 2018. Third, the spatial variation characteristics in river water quality were studied by CA and DA, and PCA/FA was used to identify potential pollution sources of rivers and confirm the spatial variation results of CA to determine the most polluted river reaches. The contribution rate of potential pollution sources in the flood season and nonflood season to each water quality parameter was further estimated by APCS-MLR. Finally, the causes of pollution formation in the most polluted river reaches were explored by the SMK test and the SMK test of flow-adjusted concentrations.

\section{Materials and Methods}

2.1. Study Area. Wei River is the main branch of the Hai River. The Wei River has a length of $388 \mathrm{~km}$ and a catchment area of $16578 \mathrm{~km}^{2}$ (Figure 1). The 9 major tributaries of the
Wei River were selected for an analysis of their water pollution, including the Communist Canal; the Yu, Shimen, Baiquan, and Cang Rivers in Northern Xinxiang; and the Dashilao, People's Victory Canal, Ximeng, and Dongmeng Rivers in Southern Xinxiang. The Communist Canal, the largest tributary of the Wei River, draws water from the Yellow River in the southern part of Xinxiang City and joins the Wei River in Hebi City and is responsible for irrigating farmland and draining floodwater from the northern mountain area into the Wei River. The mean annual discharges of the Wei River and the Communist Canal are both less than $15 \mathrm{~m}^{3} / \mathrm{s}$. The study area belongs to the continental monsoon climate zone, with a mean annual evaporation of $898.0 \mathrm{~mm}$ and an average temperature of $14^{\circ} \mathrm{C}$. The mean annual precipitation in the study area is $610.8 \mathrm{~mm}$, and approximately $70 \%$ of annual precipitation occurs during the summer season (June-September), with abundant rainstorms. The study area has undergone a reduction of precipitation in recent years. Tributaries such as the Dashilao, Baiquan, Ximeng and Dongmeng Rivers flow through densely populated areas with developed industry and agriculture, which are the major rivers carrying pollutants, and river water pollution is more serious.

2.2. Data Collection. The monthly water quality data and daily flow data were provided by the Henan Hydrology and Water Resources Survey Bureau. There were 9 monitoring sites (G1-G9) along the mainstream and 10 monitoring sites (Z1-Z10) along the tributaries, namely, 6 monitoring sites along the Wei River, 3 monitoring sites along the Communist Canal, 2 monitoring sites along the Yu River, 2 monitoring sites along the Shimen River, and 1 monitoring site along each of the other rivers. Sites Z3, Z4, and Z10 were located in the Baoquan Reservoir, Shimen Reservoir, and Tagang Reservoir, respectively. Water quality data were collected from 2013 to 2018, with additional time series data from 1980 to 2018 at site G2 and from 1982 to 2018 at site G4. Flow data were collected from 2013 to 2018. Table 1 provides information of the major rivers and 19 monitoring sites.

The 15 water quality parameters at each monitoring site included water temperature (Temp), $\mathrm{pH}$, dissolved oxygen $(\mathrm{DO})$, chemical oxygen demand $\left(\mathrm{COD}_{\mathrm{Cr}}\right)$, 5-day biochemical oxygen demand $\left(\mathrm{BOD}_{5}\right)$, ammonium nitrogen $\left(\mathrm{NH}_{3}-\mathrm{N}\right)$, total phosphorus (TP), fluorine $\left(\mathrm{F}^{-}\right)$, cyanide $(\mathrm{CN})$, volatile phenol $(\mathrm{VP})$, cuprum $(\mathrm{Cu})$, zinc $(\mathrm{Zn})$, lead $(\mathrm{Pb})$, cadmium $(\mathrm{Cd})$, and chromium $\left(\mathrm{Cr}^{6+}\right)$. These parameters reflect the physical properties, organic constituents, biological properties, and nutrient constituents of the rivers and metals in the rivers. Sampling, preservation, transportation, and analysis of the water samples were performed according to the environmental quality standards for surface water of China (GB3838-2002) [34]. This standard divides water quality into five grades (I-V) in accordance with environmental functions and protective objectives. Grades I and $\mathrm{V}$ correspond to the best and worst water quality, respectively. The grade III was frequently used in assessing the water quality in China because it indicated the water was suitable for fish, aquaculture, and swimming. 


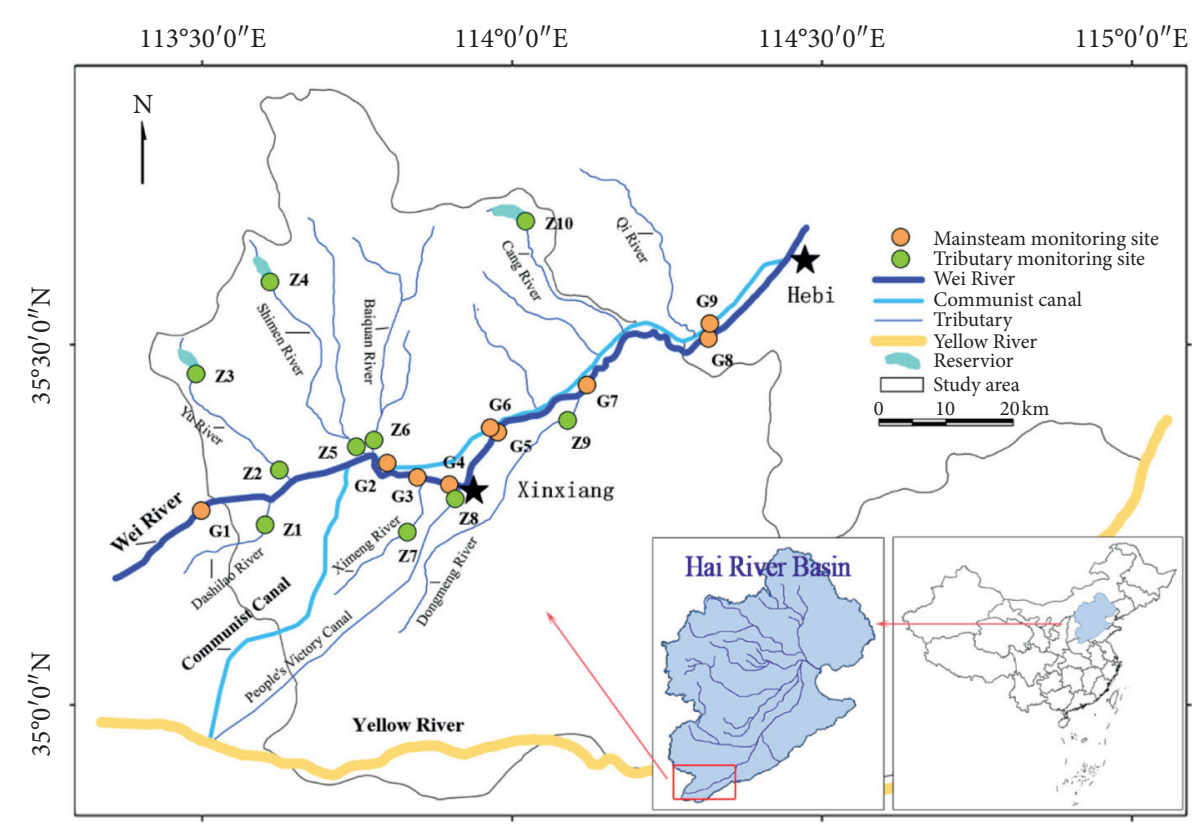

FIgURE 1: Map of the study area and surface water monitoring sites in the Xinxiang Section of the Wei River (XSWR).

TABLE 1: River water monitoring sites.

\begin{tabular}{lccc}
\hline River name & Code & $\begin{array}{c}\text { Number of monitoring } \\
\text { sites }\end{array}$ & Parameters \\
\hline Wei & $\mathrm{G} 1, \mathrm{G} 3, \mathrm{G} 4, \mathrm{G} 5, \mathrm{G} 7$, & 6 & \\
Communist & $\mathrm{G} 8$ & 3 & \\
Dashilao & $\mathrm{G} 2, \mathrm{G} 6, \mathrm{G} 9$ & 1 & \\
Yu & $\mathrm{Z} 2, \mathrm{Z3}$ & 2 & \\
Shimen & $\mathrm{Z} 4, \mathrm{Z} 5$ & 2 & \\
Baiquan & $\mathrm{Z} 6$ & 1 & $\mathrm{Cd}, \mathrm{Cr}^{6+}$ \\
Ximeng & $\mathrm{Z} 7$ & 1 & $\mathrm{TH}, \mathrm{DO}, \mathrm{COD}_{\mathrm{Cr}}, \mathrm{BOD}_{5}, \mathrm{NH}, \mathrm{VP}, \mathrm{Cu}, \mathrm{Zn}, \mathrm{Pb}$, \\
People's & $\mathrm{Z} 8$ & 1 & \\
Victory & $\mathrm{Z} 9$ & 1 & \\
Dongmeng & $\mathrm{Z} 10$ & 1 & \\
Cang & & & \\
\hline
\end{tabular}

2.3. Statistical Analysis. Cluster analysis (CA) can be used to classify or cluster objects based on their similarity $[3,35]$. Hierarchical cluster analysis (HCA) is one of the most common CA methods that could reduce the dimensionality of the original data dramatically [26]. HCA using Ward's method with the squared Euclidean distance was adopted in this study [36]. The standardized quotient between the linkage distances for a particular case divided by maximal linkage distance is expressed as $\left(D_{\text {link }} / D_{\max }\right) \times 100$ [37]. Discriminant analysis (DA) is usually used to confirm clusters found by CA and to identify significant parameters [38]. Standard and stepwise modes of DA were used in this paper.

Principal component analysis (PCA) is a dimensionreduction technique that attempts to explain the information of a large set of original variables by transforming them into a smaller set of variables, thus achieving the purpose of data reduction [39]. Factor analysis (FA) further reduces the contribution of these less significant variables through
VARIMAX rotation and produces new groups of variation called variance factors (VFs) [28]. VFs were extracted based on the principle of the cumulative contribution of variance $\geq 80 \%$. The VFs are explained based on the factor loadings, which were classified as "strong," "moderate," and "weak," corresponding to absolute loading values of $>0.75$, $0.75-0.50$, and $0.50-0.30$ [40]. To understand the comprehensive pollution status, FA was also performed to calculate the total factor scores. Factor scores for each factor at different sampling sites were calculated based on the Anderson-Rubin method [13]. The total factor scores of different sampling sites were estimated by the factor scores and eigenvalues [13]. To examine the suitability of the data for PCA/FA, the Kaiser-Meyer-Olkin (KMO) test and Bartlett's sphericity test were applied to the prepared datasets [5]. PCA/FA can be applied to the data to achieve significant reduction in the dimensionality of the original dataset only $\mathrm{KMO}>0.5$ and $P<0.05$ (at a significance level of 0.05 ) $[41,42]$. 
A nonparametric method, the seasonal Mann-Kendall (SMK) test, was used to identify whether there was a monotonic trend (i.e., increase or decrease through time) of the water quality parameters by comparing the pollutant concentrations of individual months over the years [43]. The SMK test of the flow-adjusted concentrations was used to further analyze the trends in the water quality parameters after the removal of flow [44]. If the significance level was $\leq 0.01$, the water quality trend was statistically significant. If the significance level fell in the range $0.01<a \leq 0.1$, the trend was not statistically significant. If the significance level was $>0.1$, there was no trend in the time series (trendless time series).

\subsection{Modeling}

2.4.1. CWQI. The CWQI is based on five levels of the environmental quality standard for surface water of China, with $\mathrm{COD}_{\mathrm{Mn}}, \mathrm{BOD}_{5}, \mathrm{DO}, \mathrm{NH}_{3}-\mathrm{N}$, and TP being the primary physiochemical variables [1]. CWQI is calculated according to the dissolved oxygen variable and the undissolved oxygen variables, respectively. In this study, $\mathrm{COD}_{\mathrm{Cr}}$ was used instead of $\mathrm{COD}_{\mathrm{Mn}}$. The CWQI of DO was calculated as follows:

$$
\mathrm{CWQI}_{i}= \begin{cases}1, & C_{i} \geq S_{i, 1}, \\ j+\frac{S_{i, j-1}-C_{i}}{S_{i, j-1}-S_{i, j}}, & S_{i, j} \leq C_{i}<S_{i, j-1}, \quad j=2,3,4,5, \\ 6+\frac{S_{i, 5}-C_{i}}{S_{i, 5}} \times m, & C_{i}<S_{i, 5}, \quad m=4 .\end{cases}
$$

The CWQI of some variables, such as $\mathrm{COD}_{\mathrm{Cr}}, \mathrm{BOD}_{5}$, $\mathrm{NH}_{3}-\mathrm{N}$, and TP, was calculated as follows:

$$
\mathrm{CWQI}_{i}= \begin{cases}1, & C_{i} \leq S_{i, 1}, \\ j+\frac{C_{i}-S_{i, j-1}}{S_{i, j}-S_{i, j-1}}, & S_{i, j-1}<C_{i} \leq S_{i, j}, \quad j=2,3,4,5, \\ 6+\frac{C_{i}-S_{i, 5}}{S_{i, 5}}, & C_{i}>S_{i, 5},\end{cases}
$$

where $C_{i}$ is the observed value of variable $i$; $i=\mathrm{COD}_{\mathrm{Cr}}$, $\mathrm{BOD}_{5}, \mathrm{DO}, \mathrm{NH}_{3}-\mathrm{N}$, and TP; $S_{i, j}$ is the $j$ class value of variable $i$; and $m$ is a correction coefficient. The final CWQI was the average score of all of the variables:

$$
\begin{aligned}
\mathrm{CWQI}= & \frac{1}{n}\left(\mathrm{CWQI}_{\mathrm{COD}_{\mathrm{Cr}}}+\mathrm{CWQI}_{\mathrm{BOD}_{5}}+\mathrm{CWQI}_{\mathrm{NH}_{3}-\mathrm{N}}\right. \\
& \left.+\mathrm{CWQI}_{\mathrm{TP}}+\mathrm{CWQI}_{\mathrm{DO}}\right) .
\end{aligned}
$$

The CWQI index increases with an increasing degree of pollution, and a CWQI value greater than 7.0 indicates black-odorous water.
2.4.2. APCS-MLR. Absolute principal component scoremultiple linear regression (APCS-MLR) was used to conduct multiple linear regressions of the water quality parameters and absolute factor scores to identify the contribution rate of the factors to each water quality parameter [45], which can expressed as

$$
M_{i}=r_{i 0}+\sum_{j=1}^{p} r_{i j} \times(\mathrm{APCS})_{j k},
$$

where $M_{i}$ is the concentration of different water quality variable $i, r_{i 0}$ is the constant obtained by the MLR analysis of the water quality variable $i, r_{i j}$ is the regression coefficient of the water quality variable $i$ and the extraction factor $j$, and (APCS) ${ }_{j k}$ is the absolute principal components score of extraction factor $j$ of the sample $k$. The $k$ and $p$ represent the total number of samples and extraction factors, respectively. In general, the coefficients of determination $R^{2}>0.5$ and $P<0.05$ demonstrate that the result of APCS-MLR model was reliable [41].

2.5. Data Treatment. For statistical analysis (CA, DA, and PCA/FA) and APCS-MLR, the median pollutant concentration was determined to represent the overall water quality status from 2013 to 2018. The following data pretreatment methods were used for the water quality dataset: (i) values below the lower bounds were replaced with the midvalue between zero and the detection limit; (ii) the Kolmogorov-Smirnov (K-S) statistic was processed to test the normal distribution of the data since most multivariate statistical analyses require the variables to be normally distributed [46]. The K-S test is simple to use and is computationally efficient. Therefore, data with a nonnormal distribution were logarithmically transformed [27]. To avoid misclassification due to wide differences in data dimensionality, all the logtransformed variables were further $z$-scale standardized for CA, PCA/FA, and APCS-MLR analyses, whereas the original data were still used for DA analysis [47]. Details of standardization of data can be found in [42].

All mathematical computations were performed using Microsoft Office Excel 2007 (Microsoft Corporation, Redmond, WA, USA) and SPSS 22.0 (IBM Corporation, Armonk, NY, USA). The SMK test developed by the United States Geological Survey (USGS) was used.

\section{Results and Discussion}

3.1. Evaluation of River Water Quality. The summary characteristics of each parameter from 2013 to 2018 from 19 monitoring sites and from the guidelines of the national standard for surface water quality are shown in Table 2. By comparing each parameter's mean value and the associated national standard, it can be seen that the overall water quality of the XSWR is poor. The mean temperature reached $18.47{ }^{\circ} \mathrm{C}$, ranging from $1.50{ }^{\circ} \mathrm{C}$ to $33.50{ }^{\circ} \mathrm{C}$. Six $\left(\mathrm{COD}_{\mathrm{Cr}}\right.$, $\mathrm{BOD}_{5}, \mathrm{NH}_{3}-\mathrm{N}, \mathrm{TP}, \mathrm{F}^{-}$, and VP) out of 13 parameters (not including Temp and DO) were greater than the requirement of standard III. COD $\mathrm{Cr}, \mathrm{NH}_{3}-\mathrm{N}$, and TP were greater than 
TABLE 2: Statistics of the measured parameters and the national standards for surface water quality.

\begin{tabular}{|c|c|c|c|c|c|c|c|c|c|c|c|}
\hline \multicolumn{7}{|c|}{ Summary statistics of measured parameters } & \multicolumn{5}{|c|}{ Environmental quality standard $^{1}$} \\
\hline Parameters & Unit & Minimum & Maximum & Mean & $\mathrm{SD}$ & $\mathrm{CV} \%$ & I & II & III & IV & V \\
\hline $\mathrm{T}$ & ${ }^{\circ} \mathrm{C}$ & 1.50 & 33.50 & 18.47 & 8.31 & 45.01 & - & - & - & - & - \\
\hline $\mathrm{pH}$ & - & 6.22 & 9.43 & 7.77 & 0.48 & 6.13 & $6 \sim 9$ & $6 \sim 9$ & $6 \sim 9$ & $6 \sim 9$ & $6 \sim 9$ \\
\hline $\mathrm{DO}$ & $\mathrm{mg} / \mathrm{L}$ & 0.10 & 19.80 & 5.54 & 3.52 & 63.47 & 7.5 & 6 & 5 & 3 & 2 \\
\hline $\mathrm{COD}_{\mathrm{Cr}}$ & $\mathrm{mg} / \mathrm{L}$ & 4.20 & 230.00 & 61.45 & 34.33 & 55.86 & 15 & 15 & 20 & 30 & 40 \\
\hline $\mathrm{BOD}_{5}$ & $\mathrm{mg} / \mathrm{L}$ & 0.25 & 39.70 & 7.31 & 5.89 & 80.59 & 3 & 3 & 4 & 6 & 10 \\
\hline $\mathrm{NH}_{3}-\mathrm{N}$ & $\mathrm{mg} / \mathrm{L}$ & 0.01 & 37.10 & 5.20 & 5.24 & 100.81 & 0.15 & 0.5 & 1 & 1.5 & 2 \\
\hline $\mathrm{TP}$ & $\mathrm{mg} / \mathrm{L}$ & 0.01 & 12.41 & 0.43 & 0.65 & 153.86 & 0.02 & 0.1 & 0.2 & 0.3 & 0.4 \\
\hline $\mathrm{F}^{-}$ & $\mathrm{mg} / \mathrm{L}$ & 0.17 & 7.51 & 1.06 & 0.57 & 53.67 & 1 & 1 & 1 & 1.5 & 1.5 \\
\hline $\mathrm{CN}$ & $\mu \mathrm{g} / \mathrm{L}$ & 0.50 & 20.00 & 2.73 & 2.15 & 78.64 & 5 & 50 & 200 & 200 & 200 \\
\hline VP & $\mu \mathrm{g} / \mathrm{L}$ & 0.15 & 267.50 & 8.41 & 26.70 & 317.45 & 2 & 2 & 5 & 10 & 100 \\
\hline $\mathrm{Cu}$ & $\mu \mathrm{g} / \mathrm{L}$ & 0.50 & 399.00 & 8.30 & 28.01 & 337.36 & 10 & 1000 & 1000 & 1000 & 1000 \\
\hline $\mathrm{Zn}$ & $\mu \mathrm{g} / \mathrm{L}$ & 25.00 & 1650.00 & 78.20 & 167.32 & 213.96 & 50 & 1000 & 1000 & 2000 & 2000 \\
\hline $\mathrm{Pb}$ & $\mu \mathrm{g} / \mathrm{L}$ & 1.25 & 490.00 & 10.01 & 29.02 & 289.85 & 10 & 10 & 50 & 50 & 100 \\
\hline $\mathrm{Cd}$ & $\mu \mathrm{g} / \mathrm{L}$ & 0.25 & 39.00 & 1.33 & 2.89 & 216.61 & 1 & 5 & 5 & 5 & 10 \\
\hline $\mathrm{Cr}^{6+}$ & $\mu \mathrm{g} / \mathrm{L}$ & 2.00 & 44.00 & 2.14 & 2.22 & 103.97 & 10 & 50 & 50 & 50 & 100 \\
\hline
\end{tabular}

${ }^{1}$ Environmental Quality Standard: the environmental quality standards for surface water in China (GB 3838-2002); SD: standard deviation; CV: coefficient of variation.

requirement of standard $\mathrm{V}$, and pollution by organics and nutrients in the study area was serious. Comparing each parameter's maximum value with the associated national standard, of the 13 parameters, only $\mathrm{CN}, \mathrm{Cu}$, and $\mathrm{Cr}^{6+}$ had concentrations that met standard II, and Zn met standard IV, whereas the remaining 9 parameters had concentrations greater than the requirement of standard V. Among the coefficients of variation, the coefficient for $\mathrm{pH}(6.13 \%)$ indicated that the spatiotemporal change of $\mathrm{pH}$ is small. The coefficients of variation for $\mathrm{NH}_{3}-\mathrm{N}(100.81 \%)$, TP (153.86\%), VP (317.45\%), Cu (337.36\%), Zn (213.96\%), Pb (289.85\%), $\mathrm{Cd}(216.61 \%)$, and $\mathrm{Cr}^{6+}(103.97 \%)$ all exceeded $100 \%$, indicating that these monitoring parameters had strong spatiotemporal differences. $\mathrm{VP}, \mathrm{Cu}, \mathrm{Zn}, \mathrm{Pb}$, and $\mathrm{Cd}$ even exceeded $200 \%$, indicating that they were greatly influenced by human beings and had strong differences. Water quality parameters that values were above the requirement of standard III were found at 19 monitoring sites, indicating the water was unfit for drinking and direct contact with the human body without any form of treatment.

The organic and nutrient pollution in the study area was serious and may have caused serious disturbances to the river ecosystem, which was related to the high emissions of pollutants in the study area. In 2018, water with concentrations meeting the requirements of standard IV, standard $\mathrm{V}$, and inferior class $\mathrm{V}$ was found in $53.8 \%$ of the 160 monitoring sections in the Hai River [48]. The key pollution parameters in the Hai River were $\mathrm{COD}_{\mathrm{Cr}}, \mathrm{COD}_{\mathrm{Mn}}$, and $\mathrm{BOD}_{5}$. Organic pollutants mainly come from domestic sewage, livestock wastewater and wastewater from food, papermaking, the chemical industry, leather making, and the printing and dyeing industries [49, 50]. Among them, persistent organic pollutants (POPs) pose a serious threat to the environment and human health because of their longterm residual activity, bioaccumulation, semivolatility, and highly toxic nature [51]. Enrichment of $\mathrm{N}$ and $\mathrm{P}$ in rivers can lead to the overgrowth of algae and other aquatic plants, leading to eutrophication [52]. Nutrients mainly come from a variety of artificial and natural sources in the watershed, such as industrial wastewater, domestic sewage, and agricultural runoff $[53,54]$.

\subsection{Long-Term Temporal Patterns of CWQI and Major Pollutants}

3.2.1. Major Pollutants. Based on the analysis of the overall water quality in the study area, the long-term (1980-2018) variations and trends of the mean values of an organic matter parameter $\left(\mathrm{COD}_{\mathrm{Cr}}\right)$ and a nutrient parameter $\left(\mathrm{NH}_{3}-\mathrm{N}\right)$ in the flood season and nonflood season were selected for further analysis. Site G2 was selected to represent the water quality of the Communist Canal and site G4 to represent the water quality of the Wei River to analyze longterm temporal variations in water quality (Figure 2).

At the two monitoring sites, $\mathrm{COD}_{\mathrm{Cr}}$ mostly exceed the requirement of standard III $(20 \mathrm{mg} / \mathrm{L})$, and the $\mathrm{NH}_{3}-\mathrm{N}$ concentration also mostly exceeded the requirement of standard III $(1.0 \mathrm{mg} / \mathrm{L})$. The rivers in the study area have been seriously polluted for many years. The concentrations of the water quality parameters at both sites fluctuated during the research period, with the concentrations generally increasing first and then decreasing. The MK test was conducted on the annual mean concentrations of $\mathrm{COD}_{\mathrm{Cr}}$ and $\mathrm{NH}_{3}-\mathrm{N}$ over the study period, and the results showed that the trends were all statistically significant during the study period (at a two-tailed confidence level $a=0.05$ ). $\mathrm{COD}_{\mathrm{Cr}}$ at site $\mathrm{G} 2$ reached obvious peak values between 1995 and 2002 , with a maximum of $935 \mathrm{mg} / \mathrm{L}$ in the $2001 \mathrm{flood}$ season and 46.8 times higher than the requirement of standard III. Before 1985 and after 2012, the concentration of $\mathrm{NH}_{3}-\mathrm{N}$ was relatively low. Obvious peak values in the nonflood seasons occurred in 1988-1995, while obvious peak values in the flood seasons occurred in 2001-2009. In the 2005 flood season, the $\mathrm{NH}_{3}-\mathrm{N}$ concentration reached a maximum of $64.2 \mathrm{mg} / \mathrm{L}, 64.2$ times higher than the 


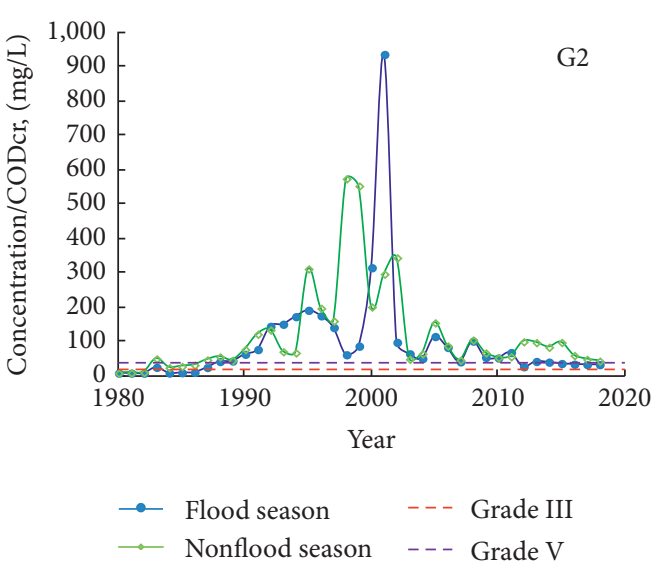

(a)

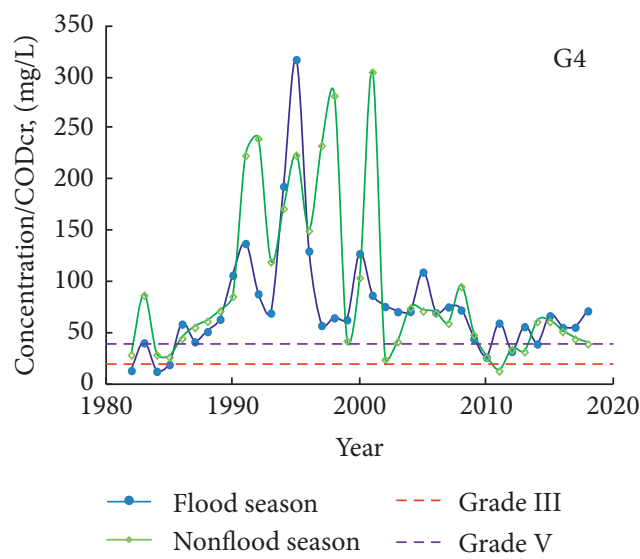

(c)

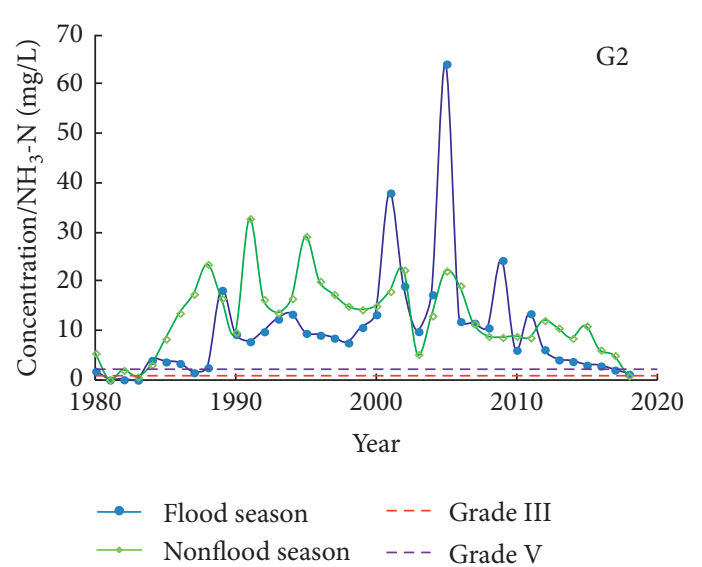

(b)

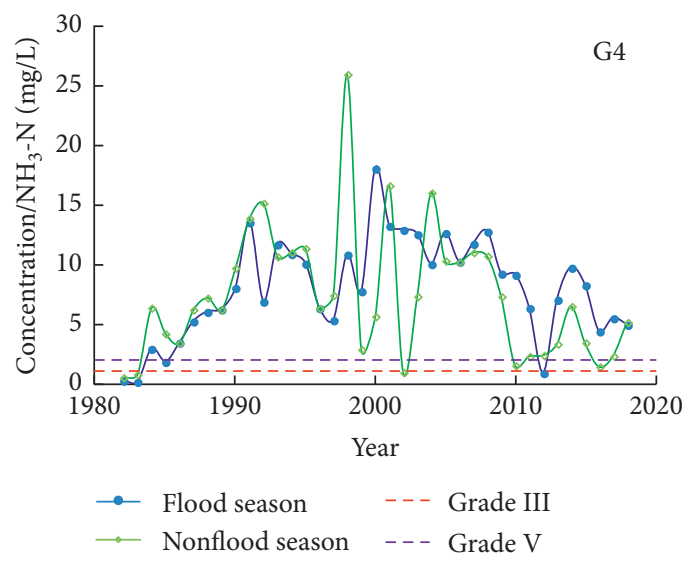

(d)

Figure 2: Trend of the temporal variations of (a) $\mathrm{COD}_{\mathrm{Cr}}$ at site $\mathrm{G} 2$, (b) $\mathrm{NH}_{3}-\mathrm{N}$ at site $\mathrm{G} 2$, (c) $\mathrm{COD}_{\mathrm{Cr}}$ at site $\mathrm{G} 4$, and (d) $\mathrm{NH}_{3}-\mathrm{N}$ at site G4.

requirement of standard III. From 1990 to 2001, $\mathrm{COD}_{\mathrm{Cr}}$ at site G4 showed obvious peak values: for example, $\mathrm{COD}_{\mathrm{Cr}}$ during the 1995 flood season was as high as $317 \mathrm{mg} / \mathrm{L}$; a decreasing trend was observed after 2009, indicating a reduction of oxygen-consuming organic matter in water body. During the monitoring period, the concentration of $\mathrm{NH}_{3}-\mathrm{N}$ was generally high between 1990 and 2009 and reached a maximum value $(25.9 \mathrm{mg} / \mathrm{L})$ in the 1998 nonflood season.

Generally, the water quality in the flood season mainly reflects the pollution intensity of nonpoint sources, while the water quality in the nonflood season can better reflect the pollution intensity of point sources. If the concentration in the dry season is obviously higher than that in the wet season, then the point source emissions have a strong influence on water quality; if the dry season concentrations are not higher than the wet season concentrations, then the nonpoint sources have a greater influence. The concentrations of the two parameters at the two water quality sites fluctuated over time throughout the flood season and nonflood season, indicating that the pollution sources change constantly.

3.2.2. CWQI. Based on the five water quality variables, the CWQI was calculated at two sites. The CWQI indexes of the water samples are presented in Figure 3. The mean CWQI

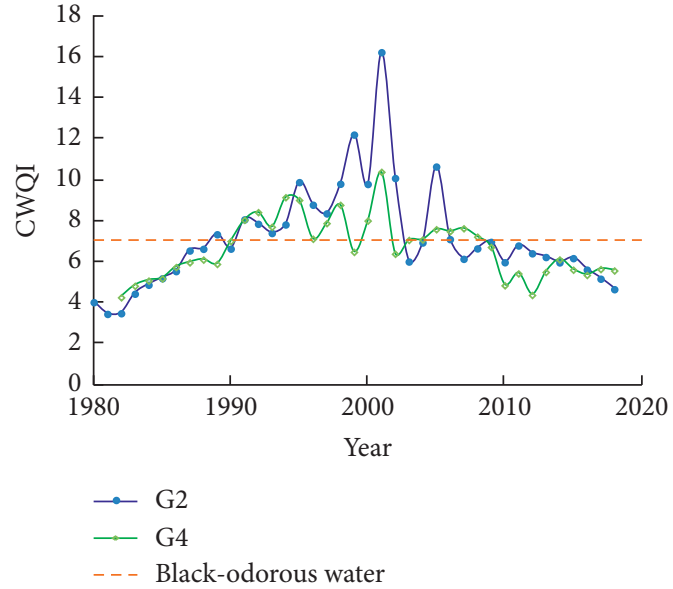

FIgURE 3: CWQI values at monitoring sites.

values at site G2 were 5.3, 8.8, and 5.9 for 1980-1990, 1991-2009, and 2010-2018, respectively. The mean CWQI values at site G4 were 5.6, 7.8, and 5.4 for 1982-1990, 1991-2009, and 2010-2018, respectively. The CWQI values at two monitoring sites for 1991-2009 were both higher than 7.0, and the color and odor of the river exhibited apparent 
blackening and odorization. The long-term temporal pattern of the CWQI index was in accordance with the major pollutants $\left(\mathrm{COD}_{\mathrm{Cr}}\right.$ and $\left.\mathrm{NH}_{3}-\mathrm{N}\right)$. These results indicated that the Wei River and the Communist Canal were lightly polluted from 1980 to 1990 and severely polluted from 1991 to 2009 , with the water quality becoming relatively better after 2010. The water quality of the Wei River and the Communist Canal showed an increasing trend of pollution, followed by a decreasing trend. A study conducted by Wang showed that the overall water quality of the Wei River mainstream improved significantly between 2005 and 2011 [55]. This was due to the fact that the government had addressed these environmental problems and taken effective management measures in recent years, and the river water quality had improved greatly.

\subsection{Spatial Variation Characteristics in Water Quality.} Based on the analysis of the long-term temporal patterns of the major pollutant concentrations in the study area, data from 2013 to 2018 were used for CA. The K-S statistical test results suggested that $\mathrm{pH}, \mathrm{DO}, \mathrm{COD}_{\mathrm{Cr}}, \mathrm{BOD}_{5}, \mathrm{NH}_{3}-\mathrm{N}, \mathrm{TP}$, and $\mathrm{F}^{-}$were normally distributed with a confidence level of 95\%. While $\mathrm{CN}, \mathrm{VP}, \mathrm{Cu}, \mathrm{Zn}, \mathrm{Pb}, \mathrm{Cd}$, and $\mathrm{Cr}^{6+}$ deviated from a normal distribution, their log-transformed variables also deviated from a normal distribution, and their median values were lower than the requirement of standard III. Therefore, seven parameters $\left(\mathrm{pH}, \mathrm{DO}, \mathrm{COD}_{\mathrm{Cr}}, \mathrm{BOD}_{5}\right.$, $\mathrm{NH}_{3}-\mathrm{N}, \mathrm{TP}$, and $\mathrm{F}^{-}$) were used in the following analysis.

The dendrogram of spatial CA is shown in Figure 4. Nineteen sampling sites can be grouped into two statistically meaningful clusters at $7<\left(D_{\text {link }} / D_{\text {max }}\right) \times 100 \leq 25 ; 19$ sampling sites can be grouped into three statistically meaningful clusters at $2<\left(D_{\text {link }} / D_{\max }\right) \times 100 \leq 7$. To confirm the clusters found by CA and identify significant parameters, standard and stepwise modes of DA were applied to discriminate the groupings, correctly assigning $100 \%$ of sites to both 2 groups and 3 groups (Table 3 ). The case of 2 groups is further discussed in this study.

Based on the analysis of the original data, cluster $A$ (Z3-Z5, Z8, Z10, and G9) and cluster B (Z1, Z2, Z6, Z7, Z9, and G1-G8) corresponded to a low pollution region and a high pollution region, respectively. The results showed that the sites of the low pollution region were mostly located at tributaries, including the Shimen River, the People's Victory Canal, the upstream reach of the Yu River, and the upstream reach of the Cang River, while the remaining tributaries and most sections of the mainstream were classified as the high pollution region. River pollution shows an obvious spatial difference. By comparing the median values of the two groups, DO in cluster A was found to be significantly higher than that in cluster $\mathrm{B}$ and the $\mathrm{pH}$ in cluster $\mathrm{A}$ was slightly higher than that in cluster $\mathrm{B}$, while $\mathrm{COD}_{\mathrm{Cr}}, \mathrm{BOD}_{5}, \mathrm{NH}_{3}-\mathrm{N}$, $\mathrm{TP}$, and $\mathrm{F}^{-}$in cluster $\mathrm{A}$ were significantly lower than that in cluster B (Figure 5). High priority to water pollution control should be given to the mainstream of the Wei River, the mainstream of the Communist Canal, the Dashilao River, the Baiquan River, the Ximeng River, and the Dongmeng River, and the downstream section of the Yu River.

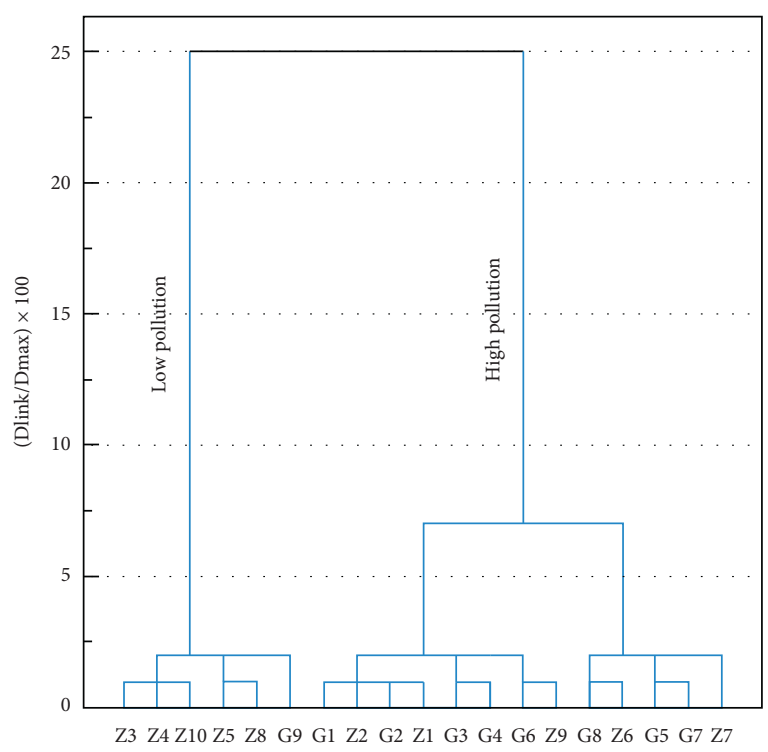

FIgURE 4: Spatial cluster analysis of pollutants in XSWR.

The upper reach of the Shimen River, the upper reach of the Yu River, and the upper reach of the Cang River, all located in the inaccessible northern mountain area, have better water quality, which represents the natural background level of water quality. The People's Victory Canal draws water from the Yellow River in the south to provide Xinxiang City with drinking water and landscape-use water. The Qi River is an unpolluted tributary, and dilution by this tributary results in improved water quality for the Communist Channel. Ding et al. [56] also confirmed that the water quality of the Communist Canal was slightly better than that of the Wei River. The other rivers were seriously polluted by domestic sewage, industrial wastewater, and agricultural runoff. In particular, the urban population of Xinxiang City is concentrated, with a population density of approximately 1600 people $/ \mathrm{m}^{2}$, and its sewage discharge affects the water quality of the lower part of the Wei River. Therefore, the spatial distribution of water quality is determined by both natural factors and human activities, and similar distribution patterns have been found in other studies. Shrestha and Kazama [17] suggested that their CA results represented the influence of land use, residential sewage, agricultural activities, and industrialization, which may have a significant impact on water quality. Huang et al. [24] used CA to divide the water quality monitoring sites of the Qiantang River into three groups, representing three pollution areas (low, medium, and high).

The results also show that CA offers a reliable classification of surface water, which provides the basis for the regional management of water quality. In addition, by selecting one or more wells within a cluster to represent the water quality of the cluster, CA will help to significantly reduce the number of sampling sites, as well as monitoring cost. For two clusters determined by DA, stepwise mode needed only two significant parameters $\left(\mathrm{COD}_{\mathrm{Cr}}\right.$ and $\left.\mathrm{BOD}_{5}\right)$ to construct the discriminant functions, which yielded a classification matrix correctly assigning 100\% of the case. 
TABLE 3: Spatial discriminant analysis of pollutants in the XSWR.

\begin{tabular}{lccccc}
\hline \multirow{2}{*}{ Groups } & \multicolumn{2}{c}{ Standard mode } & \multicolumn{2}{c}{ Stepwise mode } \\
& Correct assignations (\%) & Number of selected parameters & Correct assignations (\%) & Selected parameters \\
\hline 2 & 100.0 & 7 & 100.0 & $\mathrm{COD}_{\mathrm{Cr}}, \mathrm{BOD}_{5}$ \\
3 & 100.0 & 7 & 100.0 & DO, TP, F $^{-}$ \\
\hline
\end{tabular}

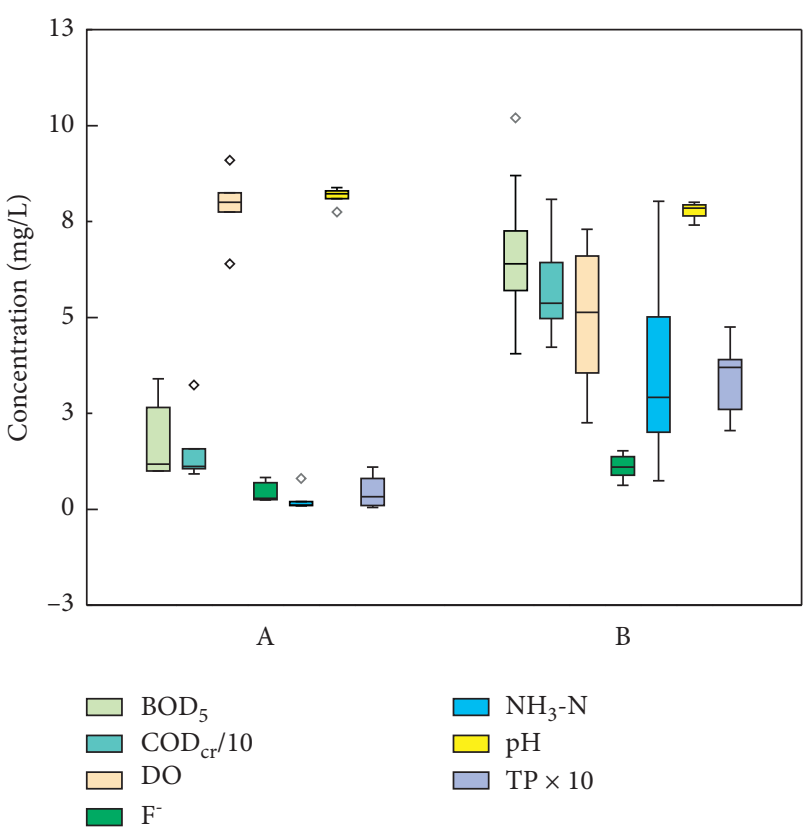

FIGURE 5: Spatial variations in pollutants in XSWR.

This means that these two parameters can replace the above seven parameters, reflecting spatial variation in water quality. DA will also help to significantly reduce the number of monitoring parameters and monitoring cost.

Since most multivariate statistical methods require variables to be normally distributed, some data were discarded in specific analyses, which could have affected the results of multivariate analysis to a certain extent [27]. This directly leads to the limitation of this paper in that it cannot fully reflect the water quality situation, which could be alleviated by increasing the number of future sampling sites and monitoring parameters.

\subsection{Source Identification and Comprehensive Assessment of Water Pollution Status}

3.4.1. Source Identification and Apportionment. The water quality parameters from 2013 to 2018 were divided into the flood season and nonflood season for PCA/FA to identify potential sources of water pollution. Both in the flood season and nonflood season, PCA/FA could be applied because it had a KMO test value of $0.7-0.8$ and Bartlett's sphericity test $P$ value of 0.00 , which were greater than the critical values. Three variance factors (VFs) were obtained for the flood season and nonflood season with the cumulative contribution of variance $\geq 80 \%$, summing almost $89.92 \%$ and $91.31 \%$ of the total variance in the dataset, respectively. The multivariate analysis results, including the factor loadings and variance contribution, are shown in Tables 4 and 5. The bold and italic values indicate strong factor loading and moderate factor loading of each factor, respectively.

In the flood season, VF1 (34.57\% of the total variance) had a strong positive loading on TP and a strong negative loading on $\mathrm{pH}$. In general, TP usually originates from domestic sewage, industrial effluent, and agricultural runoff $[39,57]$. In densely populated areas, due to inadequate or absence of wastewater treatment facilities, huge amounts of domestic and industrial effluents were discharged directly into rivers [13]. Fertilizers and pesticides were intensively applied in rural areas, and the application of synthetic $\mathrm{P}$ fertilizers (e.g., nitrophosphate fertilizer) played an important role in fertilizer input. Thus, large amounts of nutrient losses generated by excess fertilizers and pesticides quickly entered rivers through leaching and runoff during the flood season [58]. Positive correction between $\mathrm{pH}$ and $\mathrm{DO}$ can be explained as follows: as the amount of available DO decreases, an aerobic fermentation process occurs, organic acids are produced, and then, the $\mathrm{pH}$ value falls [28]. VF2 (31.35\% of the total variance) had strong positive loadings on $\mathrm{BOD}_{5}$ and $\mathrm{F}^{-}$. In the flood season, due to sufficient nutrients and an appropriate temperature, a large number of organisms grow, causing biochemical pollution [39]. $\mathrm{F}^{-}$mostly derives from industrial sewage, such as cement plants, fluorine chemical factories, and smelters [24]. In addition, Xinxiang City is a natural fluoride enrichment area, and the fluoride component of soil might increase the discharge of fluorine [59]. VF3 (24.00\% of the total variance) had a strong positive loading on $\mathrm{NH}_{3}-\mathrm{N}$, which originates mainly from domestic wastewater, industrial effluent, and agricultural runoff [18]. Untreated wastewater discharge also led to the increase in nitrogen input. Significant relationships between fertilizer and pesticide consumption and nitrogen variables were shown in rivers [13].

In the nonflood season, pollution sources might be from either point sources or nonpoint sources, but due to the low rainfall during this period ( $22 \mathrm{~mm}$ per month), it was presumed that pollution sources were unlikely to be from nonpoint sources (soil erosion, farmland, and urban runoff) [60]. VF1 (38.79\% of the total variance) had strong positive loadings on $\mathrm{COD}_{\mathrm{Cr}}$ and $\mathrm{BOD}_{5}$ and a strong negative loading on $\mathrm{DO} . \mathrm{COD}_{\mathrm{Cr}}$ and $\mathrm{BOD}_{5}$ represent the level of organic pollution in water, which mainly comes from the discharge of untreated domestic sewage and industrial effluent [27]. Degradation of highly concentrated organic matter consumes $\mathrm{DO}$ in the river, resulting in a decrease in the DO concentration [8]. VF2 (32.28\% of the total variance) had a strong positive loading on $\mathrm{NH}_{3}-\mathrm{N}$ and strong negative loading on $\mathrm{pH}$. This VF represents the contribution of 
TABLE 4: Rotated component matrix and contributions of pollutant sources in the flood season.

\begin{tabular}{|c|c|c|c|c|c|c|c|}
\hline \multirow{2}{*}{ Parameters } & \multicolumn{3}{|c|}{ Variance factors (VFs) } & \multicolumn{3}{|c|}{ Contribution percentage (\%) } & \multirow{2}{*}{$R^{2}$} \\
\hline & VF1 & VF2 & VF3 & VF1 & VF2 & VF3 & \\
\hline $\mathrm{pH}$ & -0.825 & -0.391 & -0.214 & 57.68 & 27.36 & 14.96 & 0.88 \\
\hline $\mathrm{DO}$ & -0.698 & -0.031 & -0.660 & 51.39 & - & 48.61 & 0.92 \\
\hline $\mathrm{COD}_{\mathrm{Cr}}$ & 0.655 & 0.536 & 0.374 & 41.83 & 34.28 & 23.88 & 0.86 \\
\hline $\mathrm{BOD}_{5}$ & 0.210 & 0.902 & 0.182 & 18.91 & 81.09 & - & 0.86 \\
\hline $\mathrm{NH}_{3}-\mathrm{N}$ & 0.327 & 0.152 & 0.922 & 23.32 & 10.87 & 65.80 & 0.98 \\
\hline $\mathrm{TP}$ & 0.784 & 0.265 & 0.420 & 53.40 & 18.04 & 28.56 & 0.86 \\
\hline $\mathrm{F}^{-}$ & 0.239 & 0.920 & 0.013 & 20.62 & 79.38 & - & 0.90 \\
\hline Total variance $(\%)$ & 34.57 & 31.35 & 24.00 & - & - & - & - \\
\hline Cumulative variance (\%) & 34.57 & 65.92 & 89.92 & - & - & - & - \\
\hline
\end{tabular}

TABLE 5: Rotated component matrix and contributions of pollutant sources in the nonflood season.

\begin{tabular}{lcccccc}
\hline \multirow{2}{*}{ Parameters } & \multicolumn{3}{c}{ Variance factors (VFs) } & \multicolumn{3}{c}{ Contribution percentage (\%) } \\
& VF1 & VF2 & VF3 & VF1 & VF2 & VF3 \\
\hline pH & -0.148 & $-\mathbf{0 . 9 2 4}$ & -0.252 & 11.16 & 69.81 & 19.03 \\
$\mathrm{DO}$ & $-\mathbf{0 . 7 6 3}$ & -0.575 & -0.097 & 57.05 & 42.95 & - \\
$\mathrm{COD}$ & $\mathbf{0 . 8 8 2}$ & 0.342 & 0.227 & 60.78 & 23.55 & 15.66 \\
$\mathrm{BOD}_{5}$ & $\mathbf{0 . 9 2 1}$ & 0.096 & 0.330 & 73.59 & - & 0.94 \\
$\mathrm{NH}_{3}-\mathrm{N}$ & 0.377 & $\mathbf{0 . 7 8 9}$ & 0.236 & 26.89 & 56.26 & 0.95 \\
$\mathrm{TP}$ & 0.529 & 0.508 & 0.540 & 33.52 & 32.24 & 34.24 \\
$\mathrm{~F}^{-}$ & 0.253 & 0.265 & $\mathbf{0 . 9 1 4}$ & 17.66 & 18.49 & 63.85 \\
Variance (\%) & 38.79 & 32.28 & 20.24 & - & - & 0.96 \\
Cumulative (\%) & 38.79 & 71.07 & 91.31 & - & - & - \\
\hline
\end{tabular}

nitrogen inputs from domestic wastewater and industrial effluent. VF3 (20.24\% of the total variance) represents the level of the $\mathrm{F}^{-}$concentration in water. $\mathrm{F}^{-}$originated from the same point sources as VF2 in the flood season. The study area has a large number of population and developed industry and population centralized areas characterized by significantly elevated COD, N, and P concentrations [13]. At present, only part of the urban sewage in the region is being treated, and sewage treatment capacity is far from enough, due to the dispersion of pollution sources in rural areas. Consequently, domestic sewage and industrial effluents were the predominant sources of the deterioration of the river water quality.

APCS-MLR was used to further calculate the contribution percentage of each VF to each water quality parameter in the flood season and nonflood season. The regression result was reliable because the regression model had a good fitted receptor $\left(R^{2}>0.80, P<0.05\right)$. In the flood season, VF1 mainly affected $\mathrm{pH}$ and TP (contribution rates: $57.68 \%$ and $53.40 \%$ ). VF2 mainly affected $\mathrm{BOD}_{5}$ and $\mathrm{F}^{-}$ (contribution rates: $81.09 \%$ and $79.38 \%$ ). VF3 mainly affected the concentration of $\mathrm{NH}_{3}-\mathrm{N}$ (contribution rate: $65.80 \%$ ). In the nonflood season, VF1 mainly affected $\mathrm{COD}_{\mathrm{Cr}}$ and $\mathrm{BOD}_{5}$ (contribution rates: $60.78 \%$ and $73.59 \%$ ). VF2 mainly affected $\mathrm{pH}$ and $\mathrm{NH}_{3}-\mathrm{N}$ (contribution rates: $69.81 \%$ and $56.26 \%$ ). VF3 mainly affected the concentration of $\mathrm{F}^{-}$(contribution rate: $63.85 \%$ ).

The results showed that the pollution sources were different in the flood season and nonflood season. During the flood season, rivers were polluted by domestic sewage, industrial wastewater, agricultural runoff, biochemical pollution, and natural sources. In the nonflood season, rivers were mainly polluted by point sources, such as domestic sewage and industrial wastewater. For watercourses that are highly disturbed by human activities, point sources such as domestic sewage and industrial wastewater are the main pollution sources, consistent with previous studies [61]. Wang et al. [60] divided the Qin River Basin into a severe pollution area (cluster A) and a light pollution area (cluster B). The pollution in cluster A mainly came from industrial activities, and the pollution in cluster B mainly came from urban point sources and agricultural and rural nonpoint sources. Putri et al. [5] applied PCA-MLR to analyze and assess the surface water quality of the Erren River in Southern Taiwan and suggested that industrial emissions contributed $72 \%$ of pollution, domestic black water contributed $16 \%$, and natural source and runoff contributed $12 \%$.

In addition, this study failed to quantify the cause-effect relationship between pollutant sources and water quality variations. Thus, the potential pollution sources could be determined by previous experience only, as we wanted to identify pollution sources quickly.

3.4.2. Comprehensive Assessment of Water Pollution Status. The total factor score for each monitoring site is shown in Figure 6. The higher the total factor score, the worse the river water quality. In the flood season, the scores of site G7, site G5, and site G8 were $0.69,0.64$, and 0.51 , respectively, indicating that water quality at these three monitoring sites was the most seriously polluted. Combined with the investigation of local sewage discharge outlets, the water pollution of site G7 and site G8 was found to be mainly 


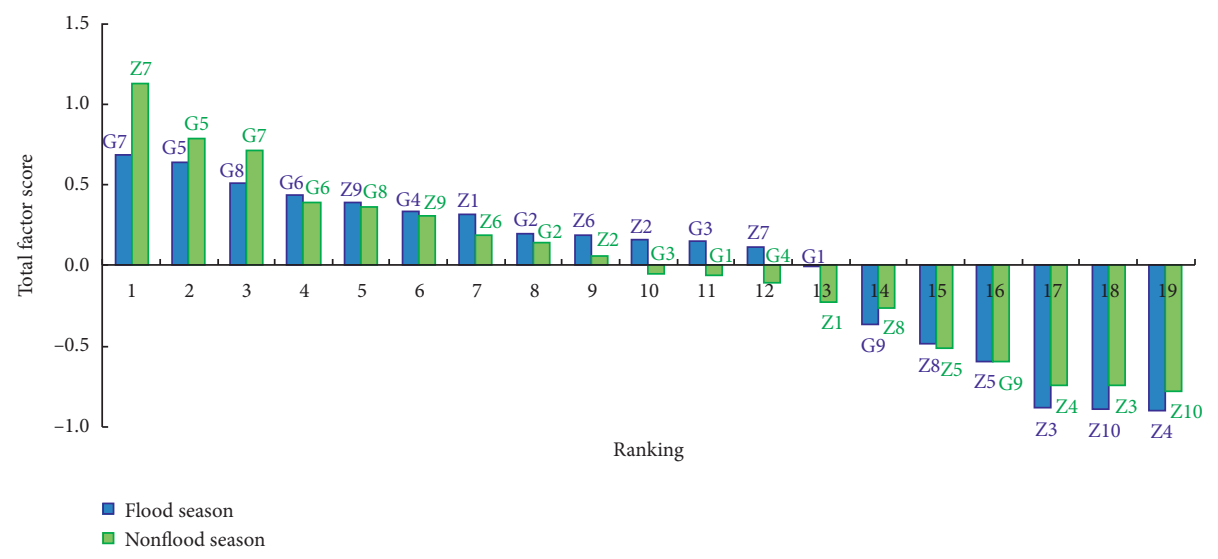

Figure 6: Total factor scores of contamination at monitoring sites.

caused by upstream water from site G5. In the nonflood season, the scores of site Z7, site G5, and site G7 were 1.13, 0.78 , and 0.71 , respectively, indicating that these three monitoring sites were the most seriously polluted. The Ximeng River flows through the plain area, which has a dense population, developed industry, and agriculture. These industries discharged a great deal of sewage and water with high concentrations of pollutants, resulting in serious pollution in this tributary. In the flood season and nonflood season, the water pollution of the mainstream of the Wei River after passing Xinxiang City was relatively serious. Site G9 in the Communist Canal had good water quality due to the dilution effect of the Qi River, a tributary of the Communist Canal. The total factor scores of the three reservoirs were the lowest found, indicating that the water quality was best in the reservoirs.

It is generally believed that the further the downstream, the greater the cumulative pollution [62]. The three reservoirs located in the upper reaches of rivers, where human activities are limited, have the best water quality. The water quality in the lower reaches of the mainstream was seriously polluted in the flood season and nonflood season. The results of FA also confirmed the clusters found by CA [36], which further suggests that surface water quality is directly related to human activities. For example, Gridharan et al. [63] found that the upper reach of the Cooum River (southern India) was divided into an unpolluted cluster, while the polluted middle and lower reaches of the river had a high population density along the watercourses and domestic sewage was discharged directly into the water bodies.

3.5. The Cause of Pollution Formation. The SMK test was conducted on the water quality of the water at site G5 during 2013-2018 (Table 6), the most polluted reach of the Wei River according to the total factor score. $R^{2}$ is a parameter reflecting the correlation between flow and pollutant concentration. The concentrations of $\mathrm{COD}_{\mathrm{Cr}}, \mathrm{NH}_{3}-\mathrm{N}, \mathrm{TP}$, and $\mathrm{F}^{-}$all showed a statistically significant downward trend, whereas the concentration of $\mathrm{BOD}_{5}$ showed a statistically significant upward trend. The decline rate $(r)$ of $\mathrm{COD}_{\mathrm{Cr}}$ was the fastest, with an annual average decrease in $4.300 \mathrm{mg} / \mathrm{L}$.
The annual average decrease rate in $\mathrm{F}^{-}$was relatively slow, at $0.067 \mathrm{mg} / \mathrm{L}$ per year.

To explore the causes of the changes in water quality, the SMK test of the flow-adjusted concentrations was used for each monitoring parameter. The residual series of flowadjusted concentrations of each parameter showed a trend basically consistent with the measured water quality data, indicating that flow was not the principal cause of the changes in water quality, which were mainly caused by reductions in pollutant emissions. The flow-adjusted concentrations of $\mathrm{COD}_{\mathrm{Cr}}, \mathrm{NH}_{3}-\mathrm{N}$, and TP showed a downward or statistically significant downward trend, indicating a decrease in pollution sources. The flow-adjusted concentration of $\mathrm{BOD}_{5}$ showed an upward trend, so its pollution sources increased. The pollution sources of $\mathrm{F}^{-}$show no obvious change. Generally speaking, if pollutants in a river mainly come from point sources, when the river flow increases, the concentrations of pollutants in the river may decrease due to the increasing effects of dilution and selfpurification [33]. Using the synchronous flow and water quality data, the relationship between each pollutant concentration variable and discharge variable was plotted. The relationship between each pollutant concentration variable and discharge variable at the monitoring site did not conform with the above rule, indicating that the water quality changes were influenced by point sources and nonpoint sources (Figure 7).

The results indicated that the water quality of seriously polluted river reaches showed an improving trend from 2013 to 2018 due to a series of measures for pollution prevention and control taken by the local government. For example, $\mathrm{COD}_{\mathrm{Cr}}$ and $\mathrm{NH}_{3}-\mathrm{N}$ were used as the main parameters for pollutant cap control; construction and renovation of municipal sewage treatment facilities were speeded up to control urban domestic sewage; industrial sewage was strictly controlled, especially along the Ximeng and Dongmeng Rivers; the distribution of rain and sewage was promoted; comprehensive measures were taken to control substandard reaches of rivers; and ecological water diversion measures were adopted, such as drawing water from the Yellow River and the South-to-North Water Transfer Project and so on. From sewage outlet surveys along the rivers, the 
TABLE 6: Results of the seasonal Mann-Kendall test and the seasonal Mann-Kendall test of flow-adjusted concentrations.

\begin{tabular}{|c|c|c|c|c|c|c|c|}
\hline \multirow[t]{2}{*}{ Monitoring site } & \multirow[t]{2}{*}{ Water quality parameters } & \multicolumn{3}{|c|}{ SMK test } & \multicolumn{3}{|c|}{$\begin{array}{l}\text { SMK test of flow-adjusted } \\
\text { concentrations }\end{array}$} \\
\hline & & $r^{*}$ & $a^{* *}(\%)$ & Trend & $R^{2 * * *}$ & $a(\%)$ & Trend \\
\hline \multirow{5}{*}{ G5 } & $\mathrm{COD}_{\mathrm{Cr}}$ & -4.300 & 0.14 & Significant downward & 0.150 & 9.27 & Downward \\
\hline & $\mathrm{BOD}_{5}$ & 1.100 & 0.09 & Significant upward & 0.087 & 3.44 & Upward \\
\hline & $\mathrm{NH}_{3}-\mathrm{N}$ & -1.587 & 0.00 & Significant downward & 0.127 & 0.03 & Significant downward \\
\hline & $\mathrm{TP}$ & -0.110 & 0.00 & Significant downward & 0.277 & 0.00 & Significant downward \\
\hline & $\mathrm{F}^{-}$ & -0.067 & 0.39 & Significant downward & 0.184 & 17.52 & No trend (trendless) \\
\hline
\end{tabular}

${ }^{*} r$ : decline rate; ${ }^{* *} a$ : significance level; ${ }^{* * *} R^{2}$ : correlation coefficient of the flow regulation formula.

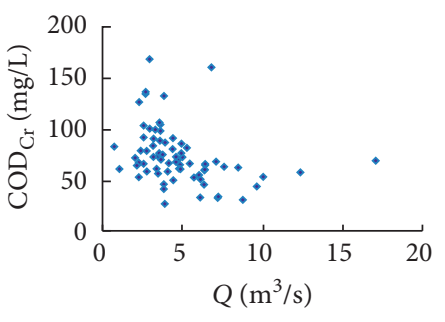

(a)

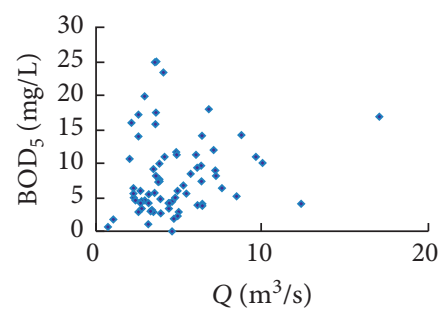

(b)

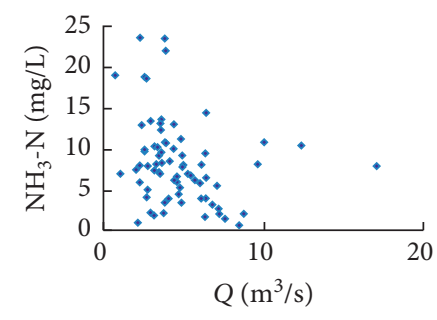

(c)

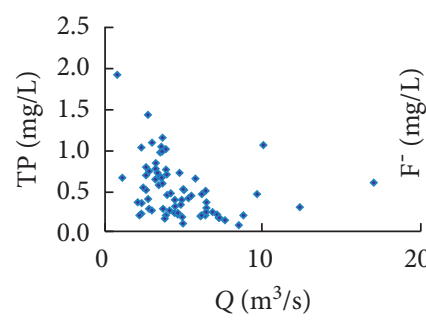

(d)

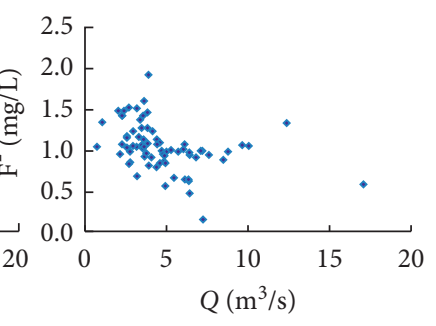

(e)

Figure 7: Relationships between the pollutant concentration and discharge at site G5: (a) $\mathrm{COD}_{\mathrm{Cr}}$; (b) $\mathrm{BOD}_{5}$; (c) $\mathrm{NH}_{3}-\mathrm{N}$; (d) TP; (e) $\mathrm{F}^{-}$.

waste discharges in 2013 and 2018 in the study area were $2.95 \times 10^{8}$ tons and $2.32 \times 10^{8}$ tons, respectively, with an average annual decline of $3.56 \%$ (Figure 8 ). Among these, the $\mathrm{NH}_{3}-\mathrm{N}$ discharge into the river decreased fast. In 2013 and $2018, \mathrm{NH}_{3}-\mathrm{N}$ discharges were 4010.20 tons and 479.91 tons, respectively, with an average annual decline of $14.67 \%$. Annual average decline of $\mathrm{COD}_{\mathrm{Cr}}, \mathrm{TP}$, and $\mathrm{TN}$ was $7.60 \%$, $11.19 \%$, and $7.09 \%$, respectively. The reduction of point sources should be one of the main reasons for the decrease in the concentrations of major pollutants.

The study also showed that the SMK test of flow-adjusted concentrations can successfully analyze the cause of pollution formation in heavily polluted rivers in densely populated areas lacking data. This method needs to calculate only the flow and water quality data to simply identify the causes of water pollution changes and quickly determine a response to management pollution sources. Therefore, managers do not need to allocate large amounts of human and material resources to collect extensive river basin data (such as meteorology, terrain, hydrology, soil type, and land use) and the water volume diverted from interbasin water transfer projects. This can save a lot of time and is computationally efficient. In particular, it is a challenge to accurately quantify the cause-effect relationship between pollutant sources and water quality variations in regions with rapid changes in pollutant sources. Although this method was enabled to draw a rough conclusion only, it can quickly solve the practical problem. 


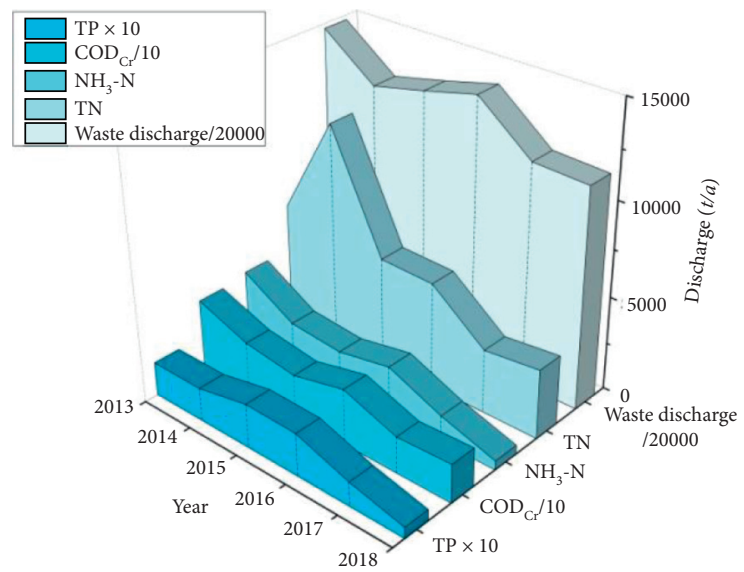

FIGURE 8: Discharges of wastewater and major pollutants into the rivers.

\section{Conclusions}

Comprehensive water quality index (CWQI), multivariate statistical techniques (MSTs), and seasonal Mann-Kendall (SMK) test and the SMK test of flow-adjusted concentrations together were applied to assess water quality of a heavily polluted river. The overall water quality in the study area indicated that water quality of the Wei River was poor and unfit for drinking purposes and for direct contact with the human body without any form of treatment. The Wei River and the Communist Canal were lightly polluted from 1980 to 1990 and severely polluted from 1991 to 2009, with the water quality becoming relatively better after 2010 . The water quality showed obvious spatial differences, which can be divided into a low pollution region (group A) and a high pollution region (group B). In the flood season, the pollution sources were mostly from domestic sewage, industrial wastewater, agricultural runoff, biochemical pollution, and natural sources. In the nonflood season, the pollution sources were mostly from domestic sewage and industrial wastewater. In recent years, the overall water quality of seriously polluted rivers has shown improvement. The concentrations of $\mathrm{COD}_{\mathrm{Cr}}, \mathrm{NH}_{3}-\mathrm{N}, \mathrm{TP}$, and $\mathrm{F}^{-}$ showed statistically significant downward trends, while the concentration of $\mathrm{BOD}_{5}$ showed a statistically significant upward trend. The main cause of water quality changes was reduction in pollutant emissions from point sources and nonpoint sources, and water quality was relatively little affected by flow. Thus, this study demonstrated that CWQI, MSTs, and SMK test and SMK test of flow-adjusted concentrations are effective approaches to assess water quality of heavily polluted rivers and can be used together as useful tools for water quality management in the future.

\section{Data Availability}

The data used to support the findings of this study are available from the corresponding author upon request.

\section{Conflicts of Interest}

The authors declare that there are no conflicts of interest regarding the publication of this paper.

\section{Acknowledgments}

This research was funded by the Government Financial Grants Project (CXGG17023) and the National Key Research and Development Program of China (2016YFC0400301).

\section{References}

[1] H. Wu, Y. Li, W. Zhang et al., "Bacterial community composition and function shift with the aggravation of water quality in a heavily polluted river," Journal of Environmental Management, vol. 237, pp. 433-441, 2019.

[2] Y. Sheng, Y. Qu, C. Ding, Q. Sun, and R. J. G. Mortimer, “A combined application of different engineering and biological techniques to remediate a heavily polluted river," Ecological Engineering, vol. 57, pp. 1-7, 2013.

[3] M. Vega, R. Pardo, E. Barrado, and L. Debán, "Assessment of seasonal and polluting effects on the quality of river water by exploratory data analysis," Water Research, vol. 32, no. 12, pp. 3581-3592, 1998.

[4] B. Gossweiler, I. Wesström, I. Messing, A. M. Romero, and A. Joel, "Spatial and temporal variations in water quality and land use in a semi-arid catchment in Bolivia," Water, vol. 11, no. 11, p. 2227, 2019.

[5] M. Putri, C.-H. Lou, M. Syai'in, S.-H. Ou, and Y.-C. Wang, "Long-term river water quality trends and pollution source apportionment in Taiwan," Water, vol. 10, no. 10, p. 1394, 2018.

[6] N. L. Poff, J. D. Allan, M. B. Bain et al., "The natural flow regime: a paradigm for river conservation and restoration," Bioscience, vol. 47, no. 11, pp. 769-784, 1997.

[7] T. Cui, F. Tian, T. Yang, J. Wen, and M. Y. A. Khan, "Development of a comprehensive framework for assessing the impacts of climate change and dam construction on flow regimes," Journal of Hydrology, vol. 590, p. 125358, 2020.

[8] M. Varol, "Use of water quality index and multivariate statistical methods for the evaluation of water quality of a stream affected by multiple stressors: a case study," Environmental Pollution, vol. 266, p. 115417, 2020.

[9] Q. Y. Zhang, J. Wei, and S. Y. Tao, "The decadal and interannual variations of drought in the Northern China and association with the circulations," Climate and Environmental Research, vol. 8, no. 3, pp. 307-318, 2003.

[10] Z. Yuan, D.-H. Yan, Z.-Y. Yang, J. Yin, and Y. Yuan, "Temporal and spatial variability of drought in Huang-Huai- 
Hai River basin, China," Theoretical and Applied Climatology, vol. 122, no. 3-4, pp. 755-769, 2015.

[11] N. Rong, B. Q. Shan, H. Zhang, C. Lin, Y. Guo, and C. Wang, "Characteristics and causes analysis of unconventional water resources supply for plain rivers in the Haihe River Basin," Acta Scientiae Circumstantiae, vol. 36, no. 2, pp. 483-490, 2016.

[12] C. Wang, H. Zhang, W. Z. Tang, B. Q. Shan, and N. Rong, "Structure analysis of river pollution source in the Haihe River Basin," Acta Scientiae Circumstantiae, vol. 35, no. 8, pp. 2345-2353, 2015.

[13] H. Bu, X. Song, and Y. Zhang, "Using multivariate statistical analyses to identify and evaluate the main sources of contamination in a polluted river near to the Liaodong Bay in Northeast China," Environmental Pollution, vol. 245, pp. 1058-1070, 2019.

[14] A. P. Singh, K. Dhadse, and J. Ahalawat, "Managing water quality of a river using an integrated geographically weighted regression technique with fuzzy decision-making model," Environmental Monitoring and Assessment, vol. 191, no. 6, p. 378, 2019.

[15] Z. Xu, "Comprehensive water quality identification index for environmental quality assessment of surface water," Journal of Tongji University, vol. 33, no. 4, pp. 482-488, 2005.

[16] V. Simeonov, J. A. Stratis, C. Samara et al., "Assessment of the surface water quality in Northern Greece," Water Research, vol. 37, no. 17, pp. 4119-4124, 2003.

[17] S. Shrestha and F. Kazama, "Assessment of surface water quality using multivariate statistical techniques: a case study of the Fuji River Basin, Japan," Environmental Modelling \& Software, vol. 22, no. 4, pp. 464-475, 2007.

[18] K. P. Singh, A. Malik, and S. Sinha, "Water quality assessment and apportionment of pollution sources of Gomti River (India) using multivariate statistical techniques-a case study," Analytica Chimica Acta, vol. 538, no. 1-2, pp. 355-374, 2005.

[19] S. Su, J. Zhi, L. Lou, F. Huang, X. Chen, and J. Wu, "Spatiotemporal patterns and source apportionment of pollution in Qiantang River (China) using neural-based modeling and multivariate statistical techniques," Physics and Chemistry of the Earth, Parts A/B/C, vol. 36, no. 9-11, pp. 379-386, 2011.

[20] J. Liang, Q. Yang, T. Sun, J. D. Martin, H. Sun, and L. Li, "MIKE 11 model-based water quality model as a tool for the evaluation of water quality management plans," Journal of Water Supply: Research and Technology-Aqua, vol. 64, no. 6, pp. 708-718, 2015.

[21] C. Wang, J. Bi, and R. B. Ambrose, "Development and application of mathematical models to support total maximum daily load for the Taihu Lake's influent rivers, China," Ecological Engineering, vol. 83, pp. 258-267, 2015.

[22] A. Li, J.-K. Jang, and P. A. Scheff, "Application of EPA CMB8.2 model for source apportionment of sediment PAHS in Lake Calumet, Chicago," Environmental Science \& Technology, vol. 37, no. 13, pp. 2958-2965, 2003.

[23] S. G. Bhanuprasad, C. Venkataraman, and M. Bhushan, "Positive matrix factorization and trajectory modelling for source identification: a new look at Indian Ocean experiment ship observations," Atmospheric Environment, vol. 42, no. 20, pp. 4836-4852, 2008.

[24] F. Huang, X. Wang, L. Lou, Z. Zhou, and J. Wu, "Spatial variation and source apportionment of water pollution in Qiantang River (China) using statistical techniques," Water Research, vol. 44, no. 5, pp. 1562-1572, 2010.

[25] B. Cao, C. Li, Y. Liu, Y. Zhao, J. Sha, and Y. Wang, "Estimation of contribution ratios of pollutant sources to a specific section based on an enhanced water quality model," Environmental Science and Pollution Research, vol. 22, no. 10, pp. 7569-7581, 2015.

[26] L. Liu, Y. Dong, M. Kong et al., "Insights into the long-term pollution trends and sources contributions in Lake Taihu, China using multi-statistic analyses models," Chemosphere, vol. 242, p. 125272, 2020.

[27] F. Zhou, G. H. Huang, H. Guo, W. Zhang, and Z. Hao, "Spatio-temporal patterns and source apportionment of coastal water pollution in Eastern Hong Kong," Water Research, vol. 41, no. 15, pp. 3429-3439, 2007.

[28] P. Chen, L. Li, and H. Zhang, "Spatio-temporal variations and source apportionment of water pollution in Danjiangkou Reservoir Basin, Central China," Water, vol. 7, no. 6, pp. 2591-2611, 2015.

[29] Q. Zhang, L. Wang, H. Wang, X. Zhu, and L. Wang, "Spatiotemporal variation of groundwater quality and source apportionment using multivariate statistical techniques for the Hutuo River alluvial-pluvial fan, China," International Journal of Environmental Research and Public Health, vol. 17, no. 3, p. 1055, 2020.

[30] C. Tanriverdi, A. Alp, A. R. Demirkiran, and F. Uçkardeş, "Assessment of surface water quality of the Ceyhan River basin, Turkey," Environmental Monitoring and Assessment, vol. 167, no. 1-4, pp. 175-184, 2010.

[31] S. Su, D. Li, Q. Zhang, R. Xiao, F. Huang, and J. Wu, "Temporal trend and source apportionment of water pollution in different functional zones of Qiantang River, China," Water Research, vol. 45, no. 4, pp. 1781-1795, 2011.

[32] R. M. Hirsch and J. R. Slack, "A nonparametric trend test for seasonal data with serial dependence," Water Resources Research, vol. 20, no. 6, pp. 727-732, 1984.

[33] R. M. Hirsch, R. B. Alexander, and R. A. Smith, "Selection of methods for the detection and estimation of trends in water quality," Water Resources Research, vol. 27, no. 5, pp. 803-813, 1991.

[34] State Environmental Protection Administration of China (SEPA), Environmental Quality Standards for Surface Water of China (GB 3838-2002), State Environmental Protection Administration of China, Beijing, China, 2002.

[35] P. Luo, S. Kang, Apip et al., "Water quality trend assessment in Jakarta: a rapidly growing Asian megacity," PLoS One, vol. 14, no. 7, p. e0219009, 2019.

[36] Y. Chen, K. Zhao, Y. Wu et al., "Spatio-temporal patterns and source identification of water pollution in lake Taihu (China),"Water, vol. 8, no. 3, p. 86, 2016.

[37] H. Pekey, D. Karakaş, and M. Bakoglu, "Source apportionment of trace metals in surface waters of a polluted stream using multivariate statistical analyses," Marine Pollution Bulletin, vol. 49, no. 9-10, pp. 809-818, 2004.

[38] R. Osman, N. Saim, H. Juahir, and M. P. Abdullah, "Chemometric application in identifying sources of organic contaminants in Langat River Basin," Environmental Monitoring and Assessment, vol. 184, no. 2, pp. 1001-1014, 2012.

[39] J. Ren, J. Liang, B. Ren, X. Zheng, and C. Guo, "New patterns of temporal and spatial variation in water quality of a highly artificialized urban river-course-a case study in the Tongzhou section of the Beiyun River," Water, vol. 10, no. 10, p. 1446, 2018.

[40] C.-W. Liu, K.-H. Lin, and Y.-M. Kuo, "Application of factor analysis in the assessment of groundwater quality in a Blackfoot disease area in Taiwan," Science of The Total Environment, vol. 313, no. 1-3, pp. 77-89, 2003. 
[41] L. Liu, Z. Tang, M. Kong et al., "Tracing the potential pollution sources of the coastal water in Hong Kong with statistical models combining APCS-MLR," Journal of Environmental Management, vol. 245, pp. 143-150, 2019.

[42] P. Bhakar and A. P. Singh, "Groundwater quality assessment in a hyper-arid region of Rajasthan, India," Natural Resources Research, vol. 28, no. 2, pp. 505-522, 2019.

[43] H. Chang, "Spatial analysis of water quality trends in the Han River basin, South Korea," Water Research, vol. 42, no. 13, pp. 3285-3304, 2008.

[44] D. R. Helsel and L. M. Frans, "Regional Kendall test for trend," Environmental Science \& Technology, vol. 40, no. 13, pp. 4066-4073, 2006.

[45] M. H. Gholizadeh, A. M. Melesse, and L. N. Reddi, "Water quality assessment and apportionment of pollution sources using APCS-MLR and PMF receptor modeling techniques in three major rivers of South Florida," Science of the Total Environment, vol. 566-567, pp. 1552-1567, 2016.

[46] B. Liang, G. Han, M. Liu et al., "Spatial and temporal variation of dissolved heavy metals in the Mun river, Northeast Thailand," Water, vol. 11, no. 2, p. 380, 2019.

[47] X. Wang, Q. Cai, L. Ye, and X. Qu, "Evaluation of spatial and temporal variation in stream water quality by multivariate statistical techniques: a case study of the Xiangxi River basin, China," Quaternary International, vol. 282, pp. 137-144, 2012.

[48] Ministry of Ecology and Environment of the People's Republic of China, "China ecological environment bulletin 2018," May 2019, http://www.mee.gov.cn/hjzl/.

[49] E. Rott, H. C. Duthie, and E. Pipp, "Monitoring organic pollution and eutrophication in the Grand River, Ontario, by means of diatoms," Canadian Journal of Fisheries and Aquatic Sciences, vol. 55, no. 6, pp. 1443-1453, 1998.

[50] Y. Wen, G. Schoups, and N. V. De Giesen, “Organic pollution of rivers: combined threats of urbanization, livestock farming and global climate change," Scientific Reports, vol. 7, p. 43289, 2017.

[51] K. W. Chau, "Persistent organic pollution characterization of sediments in Pearl River Estuary," Chemosphere, vol. 64, no. 9, pp. 1545-1549, 2006.

[52] A. Oczkowski and S. Nixon, "Increasing nutrient concentrations and the rise and fall of a coastal fishery; a review of data from the Nile Delta, Egypt," Estuarine, Coastal and Shelf Science, vol. 77, no. 3, pp. 309-319, 2008.

[53] C. Mendiguchía, C. Moreno, and M. García-Vargas, "Evaluation of natural and anthropogenic influences on the Guadalquivir River (Spain) by dissolved heavy metals and nutrients," Chemosphere, vol. 69, no. 10, pp. 1509-1517, 2007.

[54] M. I. Stutter, S. J. Langan, and R. J. Cooper, "Spatial and temporal dynamics of stream water particulate and dissolved N, P and C forms along a catchment transect, NE Scotland," Journal of Hydrology, vol. 350, no. 3-4, pp. 187-202, 2008.

[55] C. P. Wang, "Pollution characteristics and water quality trend analysis of the main stream of Wei River," China Water Resource, no. 9, pp. 58-59, 2013.

[56] L. X. Ding, B. L. Cheng, Y. C. Li, and Y. X. Lv, "Causes of environmental quality change and countermeasures in Xinxiang City," Journal of Hebei University of Environmental Engineering, vol. 22, no. 5, pp. 42-45, 2012.

[57] Y.-H. Yang, F. Zhou, H.-C. Guo et al., "Analysis of spatial and temporal water pollution patterns in Lake Dianchi using multivariate statistical methods," Environmental Monitoring and Assessment, vol. 170, no. 1-4, pp. 407-416, 2010.

[58] H. Bu, W. Meng, and Y. Zhang, "Nitrogen pollution and source identification in the Haicheng River Basin in Northeast
China," Science of the Total Environment, vol. 409, no. 18, pp. 3394-3402, 2011.

[59] C. F. Meng, X. Y. Song, W. J. Zhao, M. H. Wang, L. Xia, and $\mathrm{N}$. Fu, "Health risk assessment and the pollutant source identification of the shallow groundwater in Xinxiang rural areas," Journal of Safety and Environment, vol. 17, no. 5, pp. 2024-2030, 2017.

[60] C. Y. Wang, Y. H. Yang, F. Zhou, H. Sheng, N. Xiang, and H. C. Guo, "Spatio-temporal characteristics and source identification of water pollutants in River Qinhe Basin," Acta Scientiae Circumstantiae, vol. 32, no. 9, pp. 2267-2278, 2012.

[61] Y. Ouyang, P. Nkedi-Kizza, Q. T. Wu, D. Shinde, and C. H. Huang, "Assessment of seasonal variations in surface water quality," Water Research, vol. 40, no. 20, pp. 3800-3810, 2006.

[62] Y. Wang, S. G. Lu, Q. Feng et al., "Spatio-temporal characteristics and source identification of water pollutants in the upper and middle reachers of Heihe River," China Environmental Science, vol. 39, no. 10, pp. 4194-4204, 2019.

[63] L. Giridharan, T. Venugopal, and M. Jayaprakash, "Assessment of water quality using chemometric tools: a case study of river Cooum, South India," Archives of Environmental Contamination and Toxicology, vol. 56, no. 4, pp. 654-669, 2009. 